\title{
PERSONAL TRAVEL PLANNING: REVIEW OF SOFT TRANSPORT MEASURE CRITERIA AND EFFECTS
}

\author{
DANIELA MÜLLER-EIE, EIVIND KNUTSEN \& EILEEN P. SELLAND \\ Department of Safety, Economics, and Planning, University of Stavanger, Norway
}

\begin{abstract}
In an effort to reduce car travel and the resulting negative effects (Green House Gas (GHG) emissions, traffic congestion, inefficient land use); and to increase public and active travel modes, there has been increasing interest in soft transport measures, such as personal travel planning. While social marketing approaches to public transport and cycling have been around since the 1990s, they are increasingly used to supplement more traditional measures, such as infrastructure development and road pricing. We ask whether personal travel planning is a viable way to reduce car travel in urban areas of Norway. This paper gives an overview of factors that play into travel mode choices. It also reviews personal travel planning schemes, their characteristics and their reported effects, with the help of a literature review that was based on a set of criteria we developed. This can be applied to the mobility initiative HjemJobbHjem (Home-Work-Home) (HJH), which is currently being implemented in the Stavanger region of Norway. Thus, the initiative is evaluated in terms of goals, implementation and effect. In conclusion, we present the criteria and the value of personal travel planning for a holistic effort to reduce car travel. In particular, we describe the relevance and success of the HJH mobility initiative, its implementation, and its effects for the Stavanger region.
\end{abstract}

Keywords: sustainability, urban mobility, personal travel, personal travel planning, travel behavior, positive travel incentives, soft transport measure, Norway.

\section{INTRODUCTION}

Soft transportation measures, such as personal travel planning (PTP) and voluntary travel behavior change (VTBC) programs, can be employed as supplementary measures in the efforts to reduce the share of car travel, or to increase public and active travel (like walking and cycling). More specifically, such programs are often supplementary to more traditional measures, such as negative financial incentives (tax increases, road tools, congestion pricing, parking fees, etc.) or infrastructural changes (i.e. land use regulations, parking restrictions, public and soft transport infrastructure) in a holistic approach, to change the travel mode choice and thus, the modal split.

The purpose of these measures is to change people's travel habits by "providing individuals with tailored information based specifically on their daily needs" [1]. Thus, increased knowledge about travel alternatives, changing attitudes and positive incentives can lead to more conscious decision-making and more environmentally friendly travel mode choices [2]. Previous investigations of soft measures show varying results, but usually indicate lowering of the car shares and increases in public and active travel [3]-[11]; however, some of these evaluations have been heavily criticized with regard to data validity and research design [12]. This paper provides a review of the theoretical and conceptual background of PTP and VTBC programs, as well as a review of existing studies. In addition, the Norwegian HjemJobbHjem (Home-Work-Home) (HJH) initiative is presented and evaluated in terms of its goals, implementation and effects.

\section{TRAVEL MODE CHOICE}

Understanding a person's travel mode choice is a prerequisite to changing it. Factors for travel decisions have been divided into individual and collective, subjective and objective 
[13]. They have also been divided into attitudes, context, aptitude and habits [14]. While most hard measures cater to the rational aspects of decision-making (time, cost and distance), soft measures cater towards the more social, personal and emotional factors (like norms/values, self-perception, hedonism, and habits). As a matter of fact, decisions are more often made based on emotions, habits, preferences, social norms; even though they might compromise rational factors [15]-[17] (Fig. 1). We will, therefore, quickly review the different categories of factors for making travel choices, together with the measures that address them.

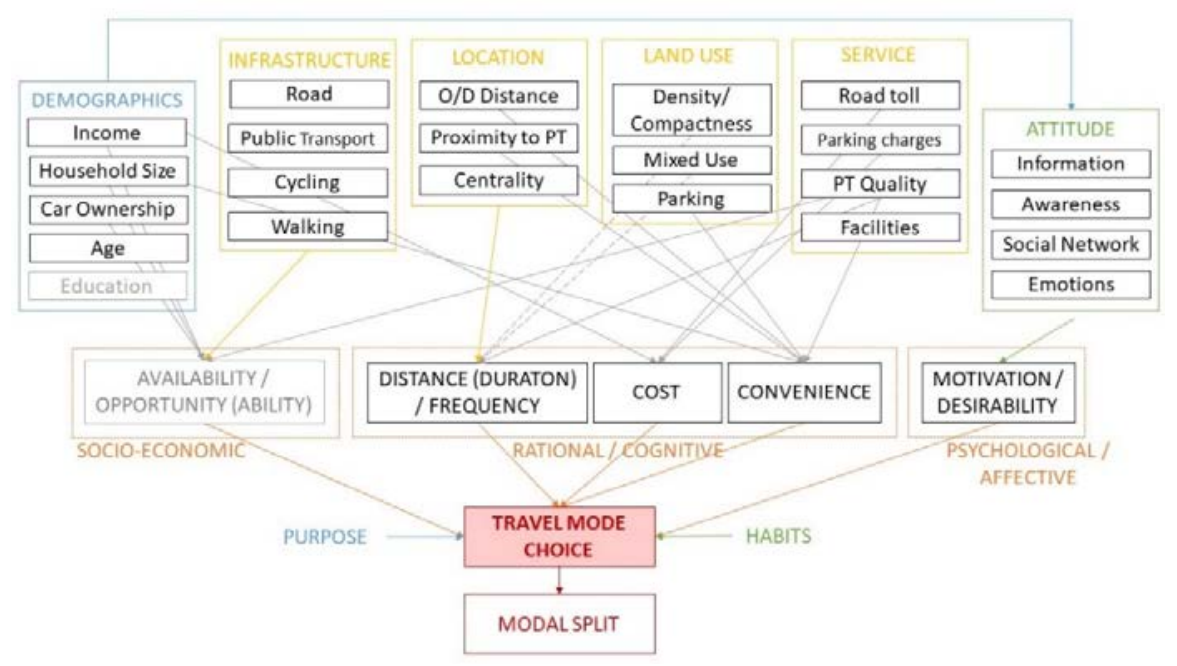

Figure 1: Hypothetical model of factors for travel mode choice. $\mathrm{O} / \mathrm{D}$ : origin-destination; PT: Public transportation.

\subsection{Physical factors and geographic factors}

The fact that an urban structure has major implications on travel has long been studied, and it is often claimed that more compact urban environments directly relate to more sustainable travel (i.e. public or soft transport). The reasoning is that for densely built environments and those with high population density, there are more daily activities within shorter travel distances provided, which usually encourages walking, cycling or travel by public transportation [18], [19]. Also, a densely built environment is usually counterproductive to car ownership, due to a lack of private parking. Therefore, strategically mixing land uses and providing many facilities for work and for daily amenities (shopping, pharmacy, post office, schools and preschools, etc.) in a compact and high-density urban environment is seen to be a viable solution.

Another important physical factor is the transportation infrastructure, such as roads, transit systems, and cycling and walking infrastructure [20]-[22]. One of the important criteria for public travel, for instance, is the distance from the home and destination to public transport stops, with recommendations of $300 \mathrm{~m}$ distance for bus or $500 \mathrm{~m}$ for rail access; however, it has been questioned whether these relations hold true in different urban environments, such as in dispersed polycentric regions [23]. All this is the rationale behind some sustainable urban development strategies, such as having high-density, compactness, autonomy, decentralized concentration, 5-minute cities, mixed use and transit-oriented development. 


\subsection{Demographic factors}

Another major factor for travel mode choice is the personal characteristics of the traveler, in terms of their socio-economic status. Income is probably the factor that has been considered the most decisive factor within the rational approaches (cost-benefit, time-budget) [24]-[26], with high income groups usually being prone to more travel and higher car use. They also tend to be less sensitive to negative financial incentives [27]. Households size, i.e. whether the traveler lives alone or in a larger family, possibly with responsibility for younger children, also seems to impact travel mode choice, with those families with young children often choosing the car, for convenience and flexibility [24], [25]. While gender, age and education are often said to influence travel decisions [24]-[26], studies show varying results.

\subsection{Social factors and networks}

Factors related to social norms and dynamics have become apparent, and were studied more recently. This includes social norms and trends, as well as group pressure [28], [29]. To which degree someone is impacted by these social norms, depends on who is promoting them, i.e. someone a person feels similar to and trusts, or someone who has little in common with people and whom they may distrust. It seems that the actions of others do highly influence our choices, meaning that travel mode choice can be viewed as a social behavior and that mode change must then adhere to similar mechanisms as for social innovation [30]. This means that explicitly taking into account social dynamics when developing travel change measures can be important.

\subsection{Psychological factors}

Furthermore, personal psychological attributes, such as values and beliefs, attitudes and perceptions, also seem to play a role in the making of travel mode choices [29], [31]. This is why personal travel change measures appeal to people's attitudes, beliefs and self-image. Taking into account not only the rational, but also affective and emotional factors such as pleasure, distress, pride, shame, and boredom may hold important potential for changing travel behavior.

\subsection{Habits}

Finally, it seems that one of the strongest indicators of future behavior is previous behavior, i.e. habits. Travel habits are automated responses to stable stimuli in the same context, and while they are useful for creating routines and predictability for the individual, they are also difficult to break [26], [28], [29], [32]. This is why it has been suggested that travel behavioral change is most likely to occur when the decision context is changing (i.e. after moving to a new house, changing jobs, or experiencing a change in family situation) or when other stimuli are provided. This is how providing information and raising awareness can become relevant. The wide range of factors and the complexity of interactions between them makes it valid and relevant to investigate supplementary soft transportation measures and their impact.

\section{TOOLS OF PERSONAL TRAVEL PLANNING}

Bonsall [12] describes personal travel planning as "provision of carefully targeted information and assistance to individuals or households in the expectation that it will encourage a voluntary shift in their travel behavior towards sustainable modes and away from car driving". This indicates the more indirect, but highly personalized nature of such 
measures. Meloni et al. [1] describe how the theory behind them comes from models of behavior, theories of change, and social marketing and persuasion techniques. Friman et al. [10] present four different dimensions when implementing a personal travel planning program: the targeting of a certain population segment, the provision of personalized information and incentives, communication and motivation, and finally, evaluation.

\subsection{Segmentation (target group)}

Selecting a target group is important, because different segments of society have different perceptions and needs (e.g. high income groups are more sensitive to time-saving, while low income groups are more sensitive to economic savings) [33]. Brög et al. [9], for instance, found that a third of respondents who did not use public transport requested structural changes (destinations, directness, frequency), while another third had personal barriers (working hours, family situation); however, the last third held only subjective objections to public transportation. Therefore, it is advisable to conduct a pre-analysis of the segments and their demography, current travel behaviors and attitudes.

\subsection{Personalization (customized information and incentives)}

Personal travel planning usually contains an offer of information and incentives, as well as asking for personal commitment and feedback. Once the target group is selected, the targeted information can be produced. This is important so that a participant can receive personalized, relevant and motivating information about their travel options. In addition, incentives, such as free or discounted tickets, bike gear or competitions, create an impetus and keep the participants motivated. Usually, a personal commitment (sometimes even in the form of a contract) formalizes goals and plans on how and when to achieve them. This also provides a basis for personal feedback and motivation.

\subsection{Communication}

In a personal transport planning or voluntary travel behavior change program, communication can be either remote (such as through posters, webpages, e-mails, short message service - SMS, or letter); or face-to-face, before an individual or in groups. While earlier approaches used home visits, personal letters and phone calls, now a more digital approach has developed, where participants use e-mail, SMS, or mobile applications to sign up, receive information and keep track of their progress. While this is a more resource-efficient approach, the earlier personal face-to-face contact may have increased a sense of personal commitment to the program.

\subsection{Evaluation}

There are two levels of evaluation that happen, first on the individual level of the participant, and second, on a program level. The participant is supposed to get feedback on their performance, according to their goals. This may be shown in terms of reduced car trips, traveled $\mathrm{km}$ using public transportation or a bike, calories burned, money saved or carbon dioxide $\left(\mathrm{CO}_{2}\right)$ saved. The program itself is often assessed through longitudinal studies of travel behavior in the population as a whole, or by a before-and-after study of the participating panel. The indicators of interest are the modal split, and the number of trips or $\mathrm{km}$ traveled using a respective travel mode. Additionally, the personal effects, such as the health benefits, time or money savings are also reported. 


\subsection{Examples and effects}

Effects from PTP have primarily been demonstrated from implementations done in Australia [6], Europe [3], [9], Japan [5] and the UK [7]; showing reductions in car use and $\mathrm{CO}_{2}$ emissions, and increases in alternative transport modes. The term PTP that is used in the UK is also referred to as Travel Blending in Australia, Travel Feedback Programs in Japan, and Individualized Travel Marketing in the USA. The most well-known programs are called IndiMark, TravelSmart, National Ttravel Behaviour Change Program, Sustainable Travel Towns Demonstration Program, Smarter Choices, and the Smart Places IniviativeInitiative. Norwegian programs include HjemJobbHjem, Mobility Oslo, and PUST.

The ability to compare between the persistence of changes across cases is very important in order to validate the measures' effectiveness [10]. Several analyses and meta-analyses show an average reduction in car use of $10 \%$, ranging between $0 \%$ and $40 \%$ [1], [3], [5]-[7], [9], [10] (Table 1). Business travel plans also have also long period of experience and refer to a declines in car use and an increases in the public travel, bicycle and walking share [34]. These too vary widely in results from place to place, whereas the Norwegian experience shows that attitudinal work combined with parking restrictions are particularly efficient [35].

\section{THE HJEM-JOBB-HJEM (HJH) INITIATIVE}

In 2016, the Norwegian mobility initiative was started by local government (four municipalities: Stavanger, Sandnes, Sola, Randaberg; and by the Rogaland County Council), and local transportation stakeholders (the Norwegian Public Roads Administration, the local public transportation provider Kolumbus, and the city bike share Bysykkelen). The measures are part of a larger effort to curb all car travel growth in the nine largest urban agglomerations in Norway [36], which among other ideas includes the introduction of toll ring roads, dedicated bus systems and bicycle highways. HJH is a supplementary initiative that aims toward "using the car when you have to, and leaving it when you can" [37], meaning that a reduction of car trips is the initiative's main explicit goal.

The measure is targeted at organizations located within the four urban municipalities and their employees, so it is only concerned with work travel. As HJH members, employees gain access to a dedicated affordable public transport ticket, free use of the city bike-share system, as well as e-bike loans and mobility counseling. In return, the company commits to having $75 \%$ of their employees participate in a travel survey prior to membership, as well as annual follow-up surveys (50\% participation). This data is used to generate knowledge about work travel behaviors in the Stavanger region of Norway, as well as to evaluate the initiative's effect. Due to the initiative's popularity, other companies are mainly self-recruiting, and thus participation in the program costs about $10 \mathrm{NOK}(\approx 1 €)$ until reaching the 200th employee, and less thereafter [37]. Once $75 \%$ of employees have taken the initial travel survey, all employees gain access to the incentives. Upon request, mobility seminars can be held, or bike-share stations can be installed (costing $25 € /$ month).

Depending on the size of the participating organization, there is subsequent contact with both the contact persons and the employees. Now there are few personal one-to-one interactions between employees and the $\mathrm{HJH}$, and the information provided is not necessarily customized to the participant. Also, the HJH-agreement is made between the organization and $\mathrm{HJH}$, so there may be a lack of personal commitment to the travel behavior changes. 
Table 1: Examples of the reported effects of personal transport planning [1], [2], [5]-[7], [9], [10].

\begin{tabular}{|c|c|c|c|}
\hline Place & Type & Effects & Source \\
\hline Australia & VTBC & $\begin{array}{l}14-23 \% \text { less VKMT } \\
10 \% \text { less car travel } \\
\text { Personal gain (time, health, money) }\end{array}$ & Taylor [6] \\
\hline $\begin{array}{l}\text { Australia, } \\
\text { South Perth }\end{array}$ & TravelSmart & $13 \%$ lasting reduction of car travel & Brög et al. [9] \\
\hline $\begin{array}{l}\text { Australia, } \\
\text { Cambridge }\end{array}$ & TravelSmart & $\begin{array}{l}7 \% \text { reduction in car travel (driver) } \\
17 \% \text { increase in sustainable travel (public, } \\
\text { bicycle, walking) }\end{array}$ & Brög et al. [9] \\
\hline Austria & IndiMark & $13 \%$ increase in public transport trips & Brög et al. [9] \\
\hline Canada & & $10 \%$ reduction in car travel & Brög et al. [9] \\
\hline UK & PTP & $\begin{array}{l}4-5 \% \text { less VKMT by car } \\
0-30 \% \text { reduction in car travel for work } \\
8-15 \% \text { reduction in car travel for school } \\
7-15 \% \text { reduction in car travel in } \\
\text { households }\end{array}$ & Cairns et al. [7] \\
\hline UK & $\begin{array}{l}\text { Marketing } \\
\text { campaign }\end{array}$ & $\begin{array}{l}1-5 \% \text { increase in bus trips } \\
12 \% \text { reduction of car trips }\end{array}$ & $\begin{array}{l}\text { Cairns et al. [7] } \\
\text { Brög et al. [9] }\end{array}$ \\
\hline $\begin{array}{l}\text { UK, } \\
\text { Hampshire }\end{array}$ & $\begin{array}{l}\text { TravelSmart } \\
\text { /IndiMark }\end{array}$ & $6 \%$ increase in public transport trips & Brög et al. [9] \\
\hline USA & & $8 \%$ reduction in car use & Brög et al. [9] \\
\hline $\begin{array}{l}\text { Germany } \\
(59 \text { projects })\end{array}$ & IndiMark & $19 \%$ increase in public transport trips & Brög et al. [9] \\
\hline Europe & & $\begin{array}{l}10-30 \% \text { increase in public transport } \\
\text { trips/year } \\
12 \% \text { fewer car trips } \\
18 \% \text { fewer car trips to work } \\
7 \% \text { reduction of car share }\end{array}$ & $\begin{array}{l}\text { Brög et al. [9] } \\
\text { Ker [3] } \\
\text { Möser and } \\
\text { Bamberg [8] } \\
\text { Meloni et al. [1] }\end{array}$ \\
\hline Japan & & $\begin{array}{l}7 \% \text { fewer car trips } \\
69 \% \text { increase in bus trips }\end{array}$ & $\begin{array}{l}\text { Taniguchi et al. } \\
{[5]}\end{array}$ \\
\hline $\begin{array}{l}\text { Sweden } \\
(25 \text { projects })\end{array}$ & IndiMark & $10 \%$ increase in public transport trips & Brög et al. [9] \\
\hline Sweden & & $\begin{array}{l}22 \% \text { fewer car trips } \\
36 \% * \text { increase in public transport trips } \\
43 \% \text { increase in bicycle trips }\end{array}$ & Friman et al. [10] \\
\hline Switzerland & IndiMark & $10 \%$ increase in public transport trips & Brög et al. [9] \\
\hline
\end{tabular}

*Average value, with effects ranging between $2 \%$ and $93 \%$ in different programs [10]. 


\subsection{Implementation}

After about a year of participation, employees are again asked to take a travel survey, revealing if there have been any changes in their work travel behavior. While some companies have received feedback on the changes in their employees' travel behavior, the evaluation through $\mathrm{HJH}$ is part of an on-going study (which this current paper is part of).

\subsection{Effects}

A preliminary evaluation of $\mathrm{HJH}$ [38] and an ongoing evaluation of the effects of implemented urban growth measures (Bymiljøpakke Nord-Jæren) on mobility in the Stavanger region of Norway show that $25 \%$ of HJH-participants $(n=6434)$ have reduced their car use between 2016 and 2018, while 12\% have increased their car use (Fig. 2). In terms of reduced car return trips to work per week, this means a net reduction of over 110,000 return trips per year, corresponding to a $15 \%$ net-reduction in car trips, for the sample overall.

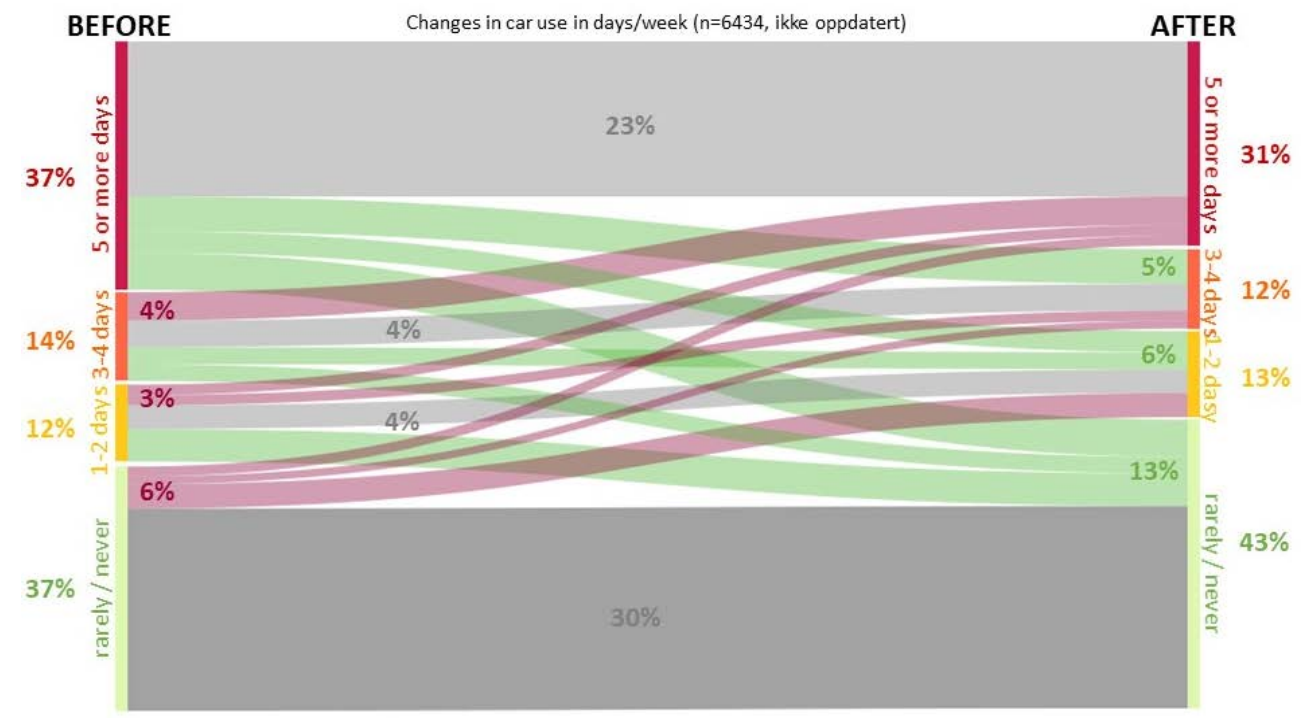

Figure 2: Changes in car use by the number of return trips per week, before and after participating in the HJH HjemJobbHjem (Home-Work-Home) program.

This analysis shows that over $60 \%$ of $\mathrm{HJH}$ participants do not change their car use at all. This might be due to infrastructural limitations, individual travel chains or personal beliefs. The fact that some people increased their car use might be due to the unintended results of having fewer cars on the road, reducing congestion and increasing the efficiency of car use, as well as increasing the availability of parking spaces. There has also been an increase in the share of electric vehicles (EVs) among the panel participants, which can result in people driving with 'a good conscience', due to having a lower environmental impact. There might also be other personal and more random reasons (like a change in their work facility situation) that can explain this increase. 
Not only have participants traveled less by car, some have also stopped driving a car all together, resulting in a reduction of the employee car share from $53 \%$ to $46 \%$ in the modal split (Fig. 3). The car was mainly substituted with public transportation, resulting in an increase of the public transportation share from $22 \%$ to $27 \%$. There were also small increases in taking car passenger rides and in walking. There seem to have been no changes in the bike share, which is surprising, given that the HJH-incentives include access to the bike share system and the loan of e-bikes.

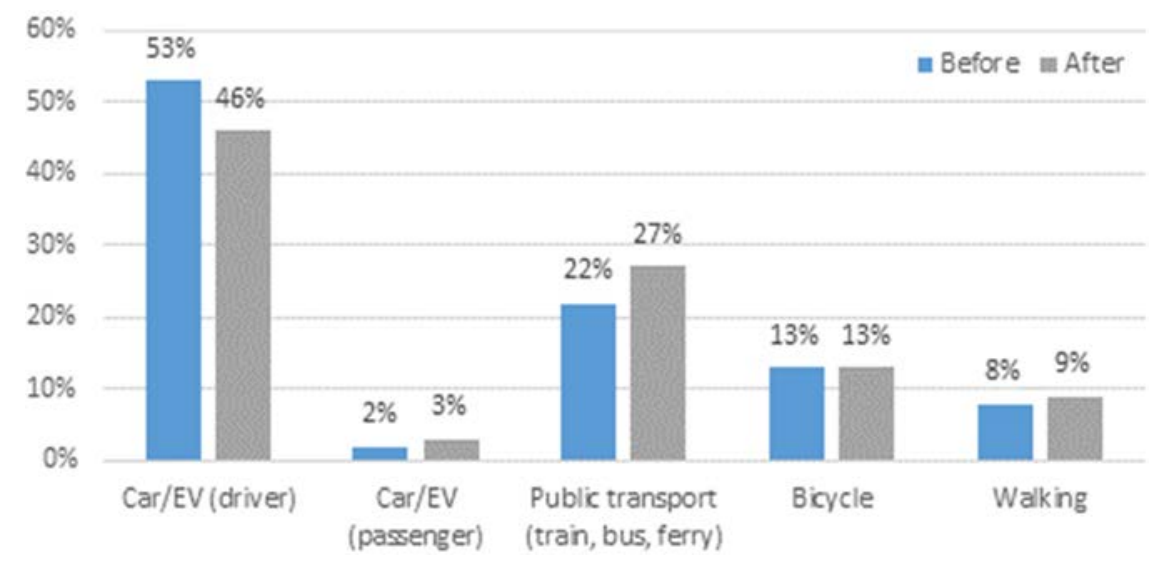

Figure 3: Changes in modal split before and after HjemJobbHjem. EV: electric vehicle.

Given that the explicit aim of HJH is to reduce the number of car trips for work travel, the results indicate that the program is effective. With a $15 \%$ reduction in car trips and a $7 \%$ reduction in the car share, the effect of HJH is also in line with other PTP programs studied; however, there seems to be further potential to increase the change towards bicycling and walking that has not been reached so far.

$\mathrm{HJH}$ is an on-going initiative that is still recruiting new participants. It is essential that the long-term effects of this measure be studied continuously.

\section{DISCUSSION}

The goal of PTP and voluntary travel behavior change programs is to reduce car travel and increase public and soft travel. While some researchers have shown positive effects on urban travel, these ideas are not without complications. Richter et al. [39], for instance, raise questions about the long-term effects of PTPs, as well as the synergies between PTP and hard transport measures. While many programs can show that their participants have reduced car use and changed their travel behavior, it is not certain which aspect of PTP is decisive for this change to occur. It may be the receipt of personalized information, personal commitment and communication with a mobility advisor, or the positive incentives of a program that lead to the behavior change; or it might be the combination of all of them. Without systemized studies, this remains a gap in knowledge.

Like other programs reviewed in the literature study, the HJH evaluation does not have a control group in the initial research design, meaning that it is difficult to say whether the changes described can be attributed to the program or other trends that impact travel behavior [9], [40]. It would be valuable to study this in more depth. However, it seems that PTP holds the potential for contributing towards reducing car travel in general. They have been shown 
to be effective in Norway, as in the case of HJH. Thus, as part of a holistic approach to achieving zero-growth in car travel, soft transport measures and PTPs such as HJH have to be seen as valuable contributing measures.

\section{ACKNOWLEDGEMENTS}

This article is based on the master theses of Eileen P. Selland and Eivind Knutsen, both master students in city and regional planning at the University of Stavanger, Norway, in 2018. This study and the master thesis are part of a larger ongoing research project executed by NORCE and UiS, funded by Rogaland County Council. This article is published with their kind permission.

\section{REFERENCES}

[1] Meloni, I., Sanjust di Teulada, B. \& Spissu, E., Lessons learned from a personalized travel planning (PTP) research program to reduce car dependence. Transportation, 44 (4), pp. 853-870, 2017.

[2] Müller-Eie, D. Personlig Transportplanlegging og Kampanjer (Personal transportation planning for Kampanjer), 2018. www.tiltak.no/b-endretransportmiddelfordeling/b-5-mobilitetsplanlegging-og-kampanjer/personligtransportplanlegging-og-kampanjer/.

[3] Ker, I., Travel demand management: Public transport business case. Victoria, Canada: Contract Report RC5051 for Department of Infrastructure, 2003.

[4] UK Department for Transportation, Making personal travel planning work. Integrated Transport Planning Ltd Research Report, 2007. http://webarchive.nationalarchives.gov.uk/20110504141946/http://www.dft.gov.uk/p gr/sustainable/travelplans/ptp/makingptpworkresearch.pdf.

[5] Taniguchi, A., Suzuki, H. \& Fujii, S., Mobility management in Japan: Its development and meta-analysis of travel feedback programs. Transportation Research Record, 2021, pp. 100-109, 2007.

[6] Taylor, M.A., Voluntary travel behavior change programs in Australia: The carrot rather than the stick in travel demand management. International Journal of Sustainable Transportation, 1(3), pp. 173-192, 2007.

[7] Cairns, S., Sloman, L., Newson, C., Anable, J., Kirkbride, A. \& Goodwin, P., Smarter choices: Assessing the potential to achieve traffic reduction using 'soft measures'. Transport Reviews, 28(5), pp. 593-618, 2008.

[8] Möser, G. \& Bamberg, S., The effectiveness of soft transport policy measures: A critical assessment and meta-analysis of empirical evidence. Journal of Environmental Psychology, 28(1), pp. 10-26, 2008.

[9] Brög, W., Erl, E., Ker, I., Ryle, J. \& Wall, R., Evaluation of voluntary travel behaviour change: Experiences from three continents. Transport Policy, 16(6), pp. 281-292, 2009.

[10] Friman, M., Larhult, L. \& Garling, T., An analysis of soft transport policy measures implemented in Sweden to reduce private car use. Transportation, 40(1), pp. 109-129, 2013.

[11] ATAP, Travel behaviour change. Transport and Infrastructure Council guidelines, 2016.

[12] Bonsall, P., Do we know whether personal travel planning really works?. Transport Policy, 16(6), pp. 306-314, 2009. 
[13] Ballard, D. \& Ballard, S., How can local authorities stimulate and support behavioural change in response to climate change?. A report for Hampshire County Council undertaken as part of the ESPACE project September 2004-May 2005, 2005.

[14] Stern, P., Toward a coherent theory of significant environmental behaviour. Journal of Social Issues, 56(3), pp. 407-424, 2000.

[15] Hounsham, S., Painting the town green: How to persuade people to be environmentally friendly. A green-engage report for everyone involved in promoting greener lifestyles to the public, 2006.

[16] Huijts, N.M.A., Molin, E.J.E. \& Steg, L., Psychological factors influencing sustainable energy technology acceptance: A review-based comprehensive framework. Renewable and Sustainable Energy Reviews, 16(1), pp. 525-531, 2012.

[17] European Commission, Trendy Travel: Emotions for sustainable transport, 2018. https://ec.europa.eu/energy/intelligent/projects/en/projects/trendy-travel.

[18] Vale, D.S., Does commuting time tolerance impede sustainable urban mobility? Analysing the impacts on commuting behaviour as a result of workplace relocation to a mixed-use centre in Lisbon. Journal of Transport Geography, 32, pp. 38-48, 2013.

[19] Buehler, R., Determinants of transport mode choice: A comparison of Germany and the USA. Journal of Transport Geography, 19(4), pp. 644-657, 2011.

[20] Engebretsen, Ø. \& Christiansen, P., Bystruktur og transport - En studie av personreiser i byer og tettsteder, Transportøkonomisk Institutt: Oslo, 2011.

[21] O'Sullivan S. \& Morrall, J., Walking distances to and from light-rail transit stations. Transportation Research Record, 1538, pp. 19-26, 1996.

[22] Song, Y. \& Knaap, G.-J., Measuring urban form: Is Portland winning the war on sprawl? Journal of the American Planning Association, 7(2), pp. 210-225, 2004.

[23] Müller-Eie, D., Geographic transport planning principles in Norwegian city regions: The case of work travel in Stavanger: Proceedings of 4th Conference on Sustainable Urban Mobility. Data Analytics: Paving the Way to Sustainable Urban Mobility, pp. 780-788, 2019.

[24] Stead, D., Williams, J. \& Titheridge, H., Land use, transport and people: Identifying the connections. Achieving Sustainable Urban Form, eds K. Williams, E. Burton \& M. Jenks, E. \& F.N. Spon: London, 2000.

[25] Gatersleben, B., Steg, L. \& Vlek, C., Measurement and determinants of environmentally significant behaviour. Environment and Behaviour, 34, p. 335, 2002.

[26] Wall, R., Psychological and contextual influences on travel mode choice for commuting. PhD thesis, De Montfort University, 2006.

[27] Müller-Eie, D., Urban environmental performance and individual behaviour: A comparison between Freiburg and Stavanger. PhD thesis, Glasgow School of Art, University of Glasgow: Glasgow, 2012.

[28] Kollmuss A. \& Agyeman, J.J., Mind the gap: Why do people act environmentally and what are the barriers to pro-environmental behavior? Environmental Education Research, 8(3), pp. 239-260, 2002.

[29] Anable, J., Lane, B. \& Kelay, T., An evidence base review of public attitudes to climate change and transport behaviour. Final Report for The Department for Transport, 2006.

[30] Müller-Eie, D. \& Bjørnø, L., Urban sustainability as social innovation. The Sustainable City IX: Urban Regeneration and Sustainability, WIT Transactions on Ecology and the Environment, vol. 191, WIT Press: Southampton and Boston, p. 197, 2014.

[31] Ampt, E., Understanding voluntary travel behaviour change. Transport Engineering in Australia, 9(2), p. 53, 2004. 
[32] Verplanken, B., Old habits and new routes to sustainable behaviour. Engaging the Public with Climate Change: Behaviour Change and Communication, eds L. Whitmarsh, S. O’Neill \& I. Lorenzoni, Earthscan: London, 2011.

[33] Asensio, J., Transport mode choice by commuters to Barcelona's CBD. Urban Studies, 39(10), pp. 1881-1895, 2002.

[34] Wake, D., TravelSmart to work: Insights from voluntary travel planning with Perth workplaces. 38th Australasian Transport Research Forum (ATRF), 2016.

[35] Sandelien, B., Grønn mobilitet - En mulighetsstudie (Green mobility - A multistudy): Statens Vegvesen (The Norwegian Public Roads Administration), 2009. www.vegvesen.no/_attachment/106296/binary/179278?fast_title $=\mathrm{Gr} \% \mathrm{C} 3 \% \mathrm{~B} 8 \mathrm{nn}+\mathrm{m}$ obilitet+.

[36] R. County Council, Bypakke Nord-Jæren, 2014. www.rogfk.no/Vaare-tjenester/ Samferdsel/Bypakke-Nord-Jaeren.

[37] HjemJobbHjem (Home-Job-Home), 2017. www.hjemjobbhjem.no/.

[38] Selland E.P. \& Knutsen, E., Faktorer for og effekter av frivillig atferdsendring ved bruk av myke mobilitetstiltak, University of Stavanger, Norway, 2018.

[39] Richter, J., Friman, M. \& Gärling, T., Soft transport policy measures: Gaps in knowledge. International Journal of Sustainable Transportation, 5(4), pp. 199-215, 2011.

[40] Stopher, P., Clifford, E., Swann, N. \& Zhang, Y., Evaluating voluntary travel behaviour change: Suggested guidelines and case studies. Transport Policy, 16(6), pp. 315-324, 2009. 